\title{
Pengaruh Penerapan Metode Demonstrasi Terhadap Prestasi Siswa Belajar
}

\author{
YETMAWATI \\ Sekolah Dasar Negeri 023 Pandau Jaya \\ Jln. AR. Rahim IV No. 1 Siak Hulu, Kampar \\ E-mail : yetmawati@yahoo.com
}

\begin{abstract}
Action research conducted with the application of the demonstration method to overcome the problem of low student achievement of learning. Through the implementation of this class action methods in primary schools and the data collected through tests and observation and analyzed using descriptive analysis. The results show that the improved understanding of fractions and their use in solving problems by elementary school students through the application of methods of demonstration. It is evident that in this study proved that the application of the method of demonstration can improve the ability of the simple fraction smoothly increased.
\end{abstract}

Keywords: Methods Demonstration, Achievement

Matematika merupakan ilmu yang universal, artinya dimana saja dan kapan saja setiap orang memerlukan matematika. Hal ini dapat kita lihat dalam kehidupan sehari-hari, maupun dalam keperluan manusia berpikir. Banyak siswa mengatakan bahwa matematika merupakan mata pelajaran yang sulit, bahkan ada yang menganggap matematika sebagai mata pelajaran yang menakutkan. Padahal matematika merupakan pelajaran yang penting bagi siswa karena mata pelajaran berfungsi untuk mengembangkan kemampuan berkomunikasi dengan menggunakan bilangan dan simbol-simbol serta ketajaman penalaran yang dapat memperjelas dan membantu menyelesaikan permasalahan dalam kehidupan seharihari.(MAIMUN JAMADI, 2015)

Pembelajaran matematika umumnya didominasi oleh pengenalan rumus-rumus serta konsep-konsep secara verbal, tanpa ada perhatian yang cukup terhadap pemahaman siswa. Disamping itu proses belajar mengajar hampir selalu berlangsung dengan metode "chalk and talk" guru menjadi pusat dari seluruh kegiatan di kelas. Pembelajaran matematika sering diinterpretasikan sebagai aktivitas utama yang dilakukan guru, yaitu guru mengenalkan materi, mungkin mengajukan satu atau dua pertanyaan, dan meminta siswa yang pasif untuk aktif dengan memulai melengkapi latihan dari buku teks, pelajaran diakhiri dengan pengorganisasian yang baik dan pembelajaran selanjutnya dilakukan dengan sekenario yang serupa. Sebagian siswa tidak mengetahui mengapa dan untuk apa mereka belajar konsep pecahan karena semua yang dipelajari terasa jauh dari kehidupan mereka sehari-hari. Siswa hanya mengenal dari apa yang digambar oleh guru di depan papan tulis atau dalam buku paket matematika, dan hampir tidak pernah mendapat kesempatan untuk memanipulasi objek-objek tersebut. (Islam et al., 2013)

Pembelajaran secara mekanistik berdampak pada ketidakbermaknaan proses belajar siswa karena matematika disajikan terpisah dari konteks yang bisa dipahami siswa pada awal pembelajaran.Sehingga konsep matematika akan cepat dilupakan oleh siswa dan siswa pun akan sulit menerapkan konsep tersebut. Permasalahan yang dirasakan selama mengajar matematika kelas III khususnya pada materi pecahan siswa masih belum memahami arti dan makna kandungan dan terkesan bingung. Hal ini dapat 
dilihat dari capaian siswa yang masih belum memenuhi standar KKM dimana dari data dapat dilihat dari KKM 70, baru yang tuntas sebanyak $40 \%$ sedangkan sisanya $60 \%$ belum tuntas.

Pemilihan pendekatan inkuiri dan metode pembelajaran eksperimen dan demonstrasi diharapkan membantu siswa mencapai keberhasilan proses pembelajaran dan menjadikan pembelajaran lebih bermakna. Namun, kenyataan di lapangan masih banyak guru yang menggunakan pola mengajar yang tradisional yaitu hanya mengajar menggunakan metoda ceramah dan bersifat satu arah (guru bicara, siswa mendengar) Susanto, dalam (Ika Candra Sayekti, 2012)

Kegiatan pembelajaran pada dasarnya dilakukan adalah untuk mencapai tujuan pembelajaran yang telah ditetapkan. Untuk mengetahui sejauh mana siswa mencapai tujuan pembelajaran yang telah ditetapkan diperlukan penilaian dengan menggunakan alat ukur tertentu. Bagi seorang guru sangat penting menguasai cara penilaian hasil belajar siswa. Penilaian yang keliru tentu sangat merugikan siswa. Penilaian dalam kegiatan pembelajaran sering disebut juga asesmen. Pengertian asesmen seringkali disamakan dengan evaluasi, padahal keduanya merupakan dua pengertian yang berbeda. Asesmen dilakukan sejak awal sampai dengan akhir pembelajaran, sedangkan evaluasi dilakukan setelah pembelajaran berakhir. Sebelum kegiatan pembelajaran berlangsung, penilaian hasil belajar siswa sudah direncanakan secara matang, sehingga penilaian bisa bersifat obyektif dan menggambarkan penguasaan hasil belajar siswa yang sebenarnya.(Zulfiani, 2010)

Uraian mengenai kondisi tersebut memberikan gambaran bahwa melalui metode demonstrasi diharapkan dapat meningkatkan prestasi belajar siswa megenai pembelajaran matematika ini.

\section{METODE}

Prosedur penelitian tindakan kelas ini merujuk pada model Kurt Lewin yang terdiri atas empat komponen pokok penelitian kelas yakni: 1) perencanaan (planning), 2) tindakan (acting), 3) pengamatan (observing), dan 4) refleksi (reflecting). Kegiatan yang dilakukan antara lain: Perencanaan, pada tahap ini penulis menyusun rencana pembelajaran (RP) materi pokok mengenai pecahan sederhana. Pada pelaksanaan siklus 1 direncanakan sebanyak 1 kali pertemuan. Pelaksanaan, penelitian tindakan kelas dilaksanakan selama pembelajaran berlangsung. Kegiatan observasi dilaksanakan secara kolaboratif dengan melibatkan rekan sejawat untuk mengamati tingkah laku dan sikap siswa ketika mengikuti pembelajaran matematika yang menerapkan model demonstrasi dalam pembelajaran matematika materi pecahan.

Setelah mengkaji hasil belajar matematika siswa dan hasil pengamatan aktivitas guru, serta menyesuaikan dengan ketercapaian indikator kinerja maka peneliti mengubah strategi pada siklus dua agar pelaksanaannya lebih efektif. Analisis data dalam penelitian tindakan kelas ini menggunakan analisis kuantitatif dan kualitatif (Supardi, 2006:131). Terhadap perolehan hasil belajar matematika dianalisis secara kuantitatif dengan memberikan nilai pada hasil belajar siswa. Data-data tersebut dianalisis mulai dari siklus satu sampai dengan siklus tuga untuk dibandingkan dengan teknik deskriptif presentase.

\section{HASIL}

Telah diketahui bahwa subjek penelitian berjumlah 32 siswa. Pelaksanaan penelitian tindakan kelas ini dilakukan dalam 3 (tiga) siklus. Berikut disajikan paparan hasil penelitian yang terdiri atas hasil belajar matematika melalui kolaborasi model pembelajaran demonstrasi dan hasil observasi terhadap proses pembelajaran.

Berdasarkan data hasil penelitian siklus I, II dan III mengenai hasil belajar matematika materi pokok mengenai 
pecahan sederhana adalah sikap rela menerima dan merasa cukup atas hasil yang diusahakannya serta menjauhkan diri dari rasa tidak puas dan perasaan kurang, melalui model pembelajaran demonstrasi, Pada siklus I, diperoleh data untuk ketuntasan 70 sebanyak $40 \%$ atau 10 orang siswa. Sedangkan yang tidak tuntas sebesar 15 atau 60\%, dan rata-rata hasil belajar sebesar 59. Pada siklus II diperoleh data untuk ketuntasan 70 sebanyak $48 \%$ atau 12 orang siswa. Sedangkan yang tidak tuntas sebesar 13 atau $52 \%$, dan rata-rata hasil belajar sebesar 68, sehingga untuk kesempurnaan perlu dilaksanakan siklus III dan pada siklus III diperoleh data untuk ketuntasan 70 sebanyak $52 \%$ atau 13 orang siswa dan ratarata hasil belajar sebesar 75 , sehingga sudah perlu dapat diakhiri penelitian ini.

Berdasarkan hasil penelitian diketahui bahwa terdapat peningkatan hasil belajar matematika dengan materi siklus pertama yakni mengenai pecahan sederhana.

Gambar 1 : Siklus Penelitian Tindakan Kelas

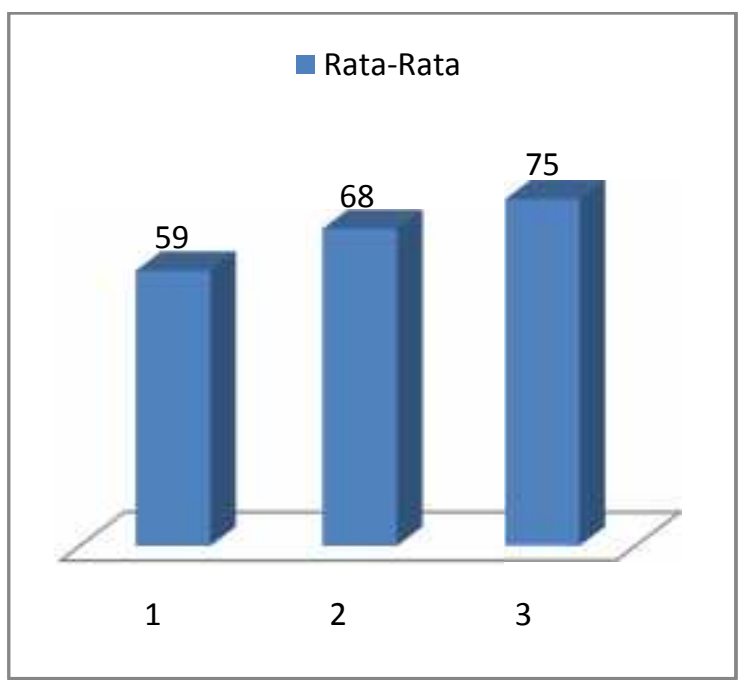

Terbukti bahwa dalam penelitian ini membuktikan bahwa penerapan metode demonstrasi dapat meningkatkan kemampuan mengenai pecahan sederhana dengan lancar mengalami peningkatan. Dampak tersebut selain secara hard skill juga mampu meningkatkan kemampuan soft skill siswa dalam belajar khususnya dalam hal sikap para siswa dalam mengikuti pelajaran karena juga merupakan target pencapaian dalam pembelajaran sudah dirasakan baik.

\section{PEMBAHASAN}

Berdasarkan hasil penelitan yang telah dilaksanakan, maka dapat ditarik beberapa kesimpulan sebagai berikut: Adanya peningkatan pemahaman pecahan dan penggunaanya dalam pemecahan masalah oleh siswa sekolah dasar melalui penerapan metode demonstrasi. Terbukti bahwa dalam penelitian ini membuktikan bahwa penerapan metode demonstrasi dapat meningkatkan kemampuan mengenai pecahan sederhana dengan lancar mengalami peningkatan. Dampak tersebut selain secara hard skill juga mampu meningkatkan kemampuan soft skill siswa dalam belajar khususnya dalam hal sikap para siswa dalam mengikuti pelajaran karena juga merupakan target pencapaian dalam pembelajaran sudah dirasakan baik.

Menurut hasil penelitian terdahulu metode yang digunakan dalam penelitian ini adalah metode Penelitian Tindakan kelas ( PTK ) yang dilaksanakan dalam II siklus di kelas II SDN I Motilango Kecamatan Anggrek Kabupaten Gorontalo Utara dengan 4 tahapan yaitu persiapan, pelaksanaan tindakan, pemantauan dan evaluasi serta analisis dan refleksi. tehnik analis data dalam penelitian ini adalah berupa lembar opservasi aktifitas guru dan siswa, tes, wawancara serta dokumentasi. Hasil penelitian menunjukan bahwa pada siklus I dari total jumlah siswa 11 orang hanya 7 orang atau $63.64 \%$ memperoleh nilai 70 ke atas dan 4 orang siswa atau $36.36 \%$ memperoleh nilai 70 ke bawah sehingga dilanjutkan pada siklus II. Pada siklus II meningkat menjadi 10 orang atau 99.91\% memperoleh nilai 70 keatas dan 1 orang atau $9.09 \%$ memperoleh nilai $70 \mathrm{ke}$ bawah. Dari hasil penelitian ini di simpulkan bahwa melalui metode demonstrasi kemampun mengenal sudut pada siswa kelas II SDN I Motilago Kecamatan Anggrek Kababupaten Gorontalo Utara meningkat.(MAIMUN JAMADI, 2015)

Hal ini mendukung hasil penelitian 
Dari hasil tindakan siklus I diperoleh ketuntasan belajar klasikal $55 \%$ dengan nilai rata-rata 6,7. Hasil tindakan siklus II diperoleh ketuntasan belajar klasikal $90 \%$ dengan nilai rata- rata 7,3. Dengan demikian dapat disimpulkan bahwa penerapan metode demonstrasi dapat meningkatkan hasil belajar siswa Kelas IVA SDN 5 Pusungi. (Ranya, Jamhari, \& Rede, 2015)

Juga menurut Rani Hasil penelitian yang diperoleh menunjukkan bahwa: 1) delapan puluh

persen siswa dalam kelas melaksanakan aktivitas belajar yang meliputi aktivitas oral, motor, dan mental dalam intensitas yang tinggi; 2) siswa melakukan aktivitas oral menjawab pertanyaan, menyampaikan dan menjelaskan secara rinci pemecahan masalah, menyampaikan pendapat, mengajukan pertanyaan, serta menanggapi penyelesaian masalah dan komentar teman sekelas; 3) siswa melakukan aktivitas motor membuat model bangun ruang berbentuk bebas, balok, dan kubus, kemudian membuat sketsanya, serta melakukan pengukuran rusuk atau panjang, lebar, dan tinggi benda berbentuk balok/kubus sebagai dasar pengukuran volume; 4) siswa melakukan aktivitas mental memahami pertanyaan, memahami instruksi, mencari hubungan, mengambil kesimpulan, menemukan rumus volume balok/kubus, membandingkan hasil kerja dengan hasil kerja siswa lain, serta menemukan penerapan matematika dalam hidup sehari-hari; dan 5) siswa memiliki minat yang tinggi terhadap pembelajaran matematika menggunakan pendekatan PMRI.(Asteria Agusti Rani, 2011)

Selain itu juga hasil penelitian Islam menunjukan bahwa penggunaan metode demonstrasi pada pembelajaran matematika dapat meningkatkan hasil belajar siswa kelas IV MI YAPPI Nglebeng berupa peningkatan nilai rata-rata kelas. Hal ini dibuktikan dengan perolehan nilai rata-rata siswa materi pecahan pada pre test atau pra penelitian hanya mencapai 61,11 , Sedangkan perolehan nilai rata-rata kelas pada siklus I sebesar 73,33, setelah mengalami perbaikan pada siklus kedua meningkat menjadi 86,67 . Hal tersebut menunjukkan bahwa aktivitas guru dan siswa dalam pembelajaran nilai pecahan dengan media membagi buah dapat ditingkatkan sehingga guru dan siswa menjadi lebih aktif.(Islam et al., 2013)

Dari hasil penelitian dan dibandingkan dengan penelitian terdahulu membuktikan bahwa metode demonstrasi mampu meningkatkan prestasi belajar matematika.

\section{SIMPULAN}

Kesimpulan yang dapat diambil adalah adanya peningkatan pemahaman pecahan dan penggunaanya dalam pemecahan masalah oleh siswa sekolah dasar melalui penerapan metode demonstrasi. Terbukti bahwa dalam penelitian ini membuktikan bahwa penerapan metode demonstrasi dapat meningkatkan kemampuan mengenai pecahan sederhana dengan lancar mengalami peningkatan.

\section{DAFTAR RUJUKAN}

Asteria agusti rani. (2011). Aktivitas dan minat belajar siswa kelas $\mathrm{v}$ dalam pembelajaran matematika dengan pendekatan pendidikan matematika realistik indonesia (pmri) di sd gambiranom yogyakarta. Skripsi.

Ika candra sayekti. (2012). Pembelajaran ipa menggunakan pendekatan inkuiri terbimbing melalui metode eksperimen dan demonstrasi ditinjau dari kemampuan analisis dan sikap ilmiah siswa. Jurnal inkuiri, 1(2), 142-153.

Islam, u., sunan, n., yogyakarta, k., sarjana, g., satu, s., \& islam, p. (2013). Upaya meningkatkan hasil belajar matematika kelas iv dengan menggunakan metode demonstrasi di mi yappi nglebeng nglipar gunungkidul. 
Maimun jamadi. (2015). Meningkatkan kemampuan mengenal sudut melalui metode demonstrasi pada kelas ii sdn i motilango kecamatan anggrek kabupaten gorontalo utara oleh. Fip ung, $1-12$.

Ranya, z. A., jamhari, m., \& rede, a. (2015). Jurnal kreatif tadulako online vol . 1 no . 2 issn 2354-614x meningkatkan hasil belajar siswa dalam pembelajaran ipa pokok bahasan panca indra dengan menggunakan metode demonstrasi pada siswa kelas 1v a sdn 5 pusungi jurnal kreatif tadulako online vol . 1. Jurnal kreatif tadulako, 1(2), 60-66.

Zulfiani. (2010). Strategi pembelajaran sains. 